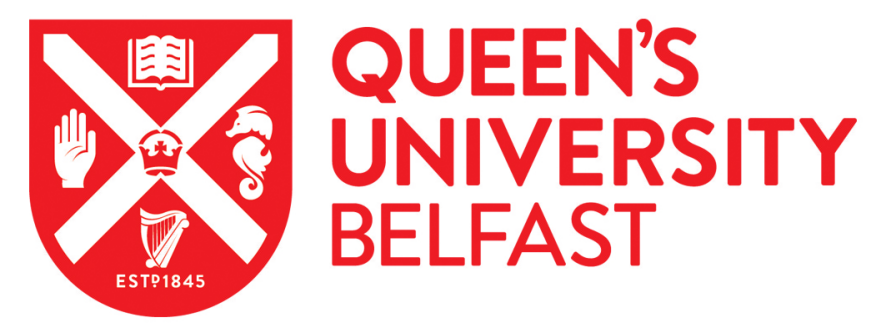

\title{
Copper uptake by four Elsholtzia ecotypes supplied with varying levels of copper in solution culture
}

Weng, G. Y., Wu, L. H., Wang, Z. Q., Luo, Y. M., \& Christie, P. (2005). Copper uptake by four Elsholtzia ecotypes supplied with varying levels of copper in solution culture. Environment International, 31(6), 880-884. https://doi.org/10.1016/j.envint.2005.05.032

Published in:

Environment International

Queen's University Belfast - Research Portal:

Link to publication record in Queen's University Belfast Research Portal

\section{General rights}

Copyright for the publications made accessible via the Queen's University Belfast Research Portal is retained by the author(s) and / or other copyright owners and it is a condition of accessing these publications that users recognise and abide by the legal requirements associated with these rights.

Take down policy

The Research Portal is Queen's institutional repository that provides access to Queen's research output. Every effort has been made to ensure that content in the Research Portal does not infringe any person's rights, or applicable UK laws. If you discover content in the Research Portal that you believe breaches copyright or violates any law, please contact openaccess@qub.ac.uk. 


\title{
Copper uptake by four Elsholtzia ecotypes supplied with varying levels of copper in solution culture
}

\author{
Gaoyi Weng ${ }^{\mathrm{a}, \mathrm{b}}$, Longhua $\mathrm{Wu}^{\mathrm{a}, *}$, Ziqiang Wang ${ }^{\mathrm{b}}$, Yongming Luo ${ }^{\mathrm{a}}$, Peter Christie ${ }^{\mathrm{c}}$ \\ ${ }^{\mathrm{a} S o i l}$ and Environment Bioremediation Research Centre, Institute of Soil Science, Chinese Academy of Sciences, PO Box 821, \\ Nanjing 210008, Jiangsu Province, PR China \\ ${ }^{\mathrm{b}}$ College of Agriculture and Biotechnology, Zhejiang University, Hangzhou 310029, PR China \\ ${ }^{\mathrm{c}}$ Agricultural and Environmental Science Department, Queen's University Belfast, Newforge Lane, Belfast BT9 5PX, UK
}

Available online 7 July 2005

\begin{abstract}
The effects of copper $(\mathrm{Cu})$ on the yield and $\mathrm{Cu}$ uptake of three ecotypes of Elsholtzia splendens and one of Elsholtzia argyi were studied using solution culture. Three $\mathrm{Cu}$ concentrations were compared: 0.31 (control), 50 and $100 \mu \mathrm{mol} \mathrm{L}{ }^{-1}$. Although E. argyi took up more $\mathrm{Cu}$ in

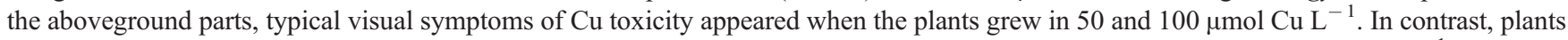
from all three populations of $E$. splendens showed high $\mathrm{Cu}$ tolerance and substantial shoot $\mathrm{Cu}$ accumulation of $58-144 \mathrm{mg} \mathrm{kg}{ }^{-1} . \mathrm{Shoot}^{\mathrm{Cu}}$ concentrations were about 16-27 times higher than root $\mathrm{Cu}$ concentrations. Root-to-shoot ratio of the E. argyi ecotype was halved when $\mathrm{Cu}$ was supplied at a level of $100 \mathrm{mg} \mathrm{L}^{-1}$ compared to the control $\left(0.31 \mathrm{mg} \mathrm{L}^{-1}\right)$ but the ratio increased by $6-47 \%$ in the three E. splendens ecotypes. The increase in root-to-shoot ratio in E. splendens may be a mechanism by which the plants can tolerate high $\mathrm{Cu}$ concentrations. There were few differences in morphology among the three E. splendens ecotypes in response to added Cu. The results are discussed in relation to the possible use of E. splendens as a pioneer species in the phytostabilization of Cu-contaminated soils.
\end{abstract}

(C) 2005 Elsevier Ltd. All rights reserved.

Keywords: Elsholtzia; $\mathrm{Cu}$ tolerance; Copper uptake; Phytostabilization

\section{Introduction}

Copper $(\mathrm{Cu})$ is an essential nutrient for plants. It is a component of several enzymes, including some that participate in electron flow and catalysis of redox reactions in plant cells (Ouzounidou et al., 1995). However, excessive $\mathrm{Cu}$ can lead to inhibition of root elongation and damage to root epidermal cells and root cell membranes (Lin et al., 2003). Excessive $\mathrm{Cu}$ may be toxic not only to plants but also to human beings via the food chain and may thus pose a potential threat to human health. Remediation measures are therefore needed for $\mathrm{Cu}$ contaminated soils.

In addition to the relatively harsh traditional engineering and chemical soil remediation methods there is a new developing phytoremediation technology in which metals

\footnotetext{
* Corresponding author. Tel.: +86 25 86881126; fax: +86 2586881128 .

E-mail addresses:1hwu0603@yahoo.com.cn, lhwu@issas.ac.cn (L. Wu).
}

are removed or stabilized by hyperaccumulator plants. Over 500 plant species can hyperaccumulate heavy metals, most of which accumulate Ni. Only a few, including Aeolanthus biformifolius and Buchnera henriquesii from central Africa, hyperaccumulate $\mathrm{Cu}$. Very few studies have been carried out on these plants because of the difficulty in obtaining plant material or seed as a result of political unrest and instability in the area (Brooks, 1998). There has therefore been considerable interest in finding alternative $\mathrm{Cu}$ accumulators.

Elsholtzia splendens is a native Chinese plant in the family Labiata. It is an annual herb with an erect stem about 15 to $120 \mathrm{~cm}$ in height which flowers in the autumn (Tang et al., 1999). This species has been called the 'copper flower' in China and has been used in the past as a $\mathrm{Cu}$ indicator in metal prospecting. The potential use of E. splendens in phytoremediation of $\mathrm{Cu}$-contaminated soils has therefore been studied by Tang et al. (2001) and Yang et al. (2002) who concluded that active adaptation and passive selection 
allow E. splendens to survive on $\mathrm{Cu}$-contaminated soils. Contrary to Yang et al. (2002), Song et al. (2004) reported that $E$. splendens did not hyperaccumulate $\mathrm{Cu}$ in pot experiments, but the shoot biomass of E. splendens was almost five times greater than that of a typical $\mathrm{Cu}$ excluder, Silene vulgaris. A second Elsholtzia species, E. argyi, was originally found growing on copper ore, and both species are widely distributed in China. The aim of the present study was to investigate whether differences exist in the degree of $\mathrm{Cu}$ tolerance and accumulation among different $E$. splendens populations and E. argyi, and also to study the effects of $\mathrm{Cu}$ on the growth and yield of Elsholtzia.

\section{Materials and methods}

\subsection{Sample collection}

Seeds were collected from three populations of E. splendens growing on $\mathrm{Cu}$ tailings. One population was near the city of Tongling in Anhui Province and other two were near the cities of Jiande and Zhuji in Zhejiang Province. E. argyi seed was collected from $\mathrm{Cu}$ mine tailings in Sanmen county, Zhejiang Province. All four sites are located in subtropical east China.

\subsection{Cultural conditions}

The seeds were placed in a 1:1 (v/v) mixture of perlite and vermiculite within 1.5 -L plastic containers in a growth chamber. The medium was kept moist with daily addition of distilled water. The growth chamber conditions were as follows: temperature of $25{ }^{\circ} \mathrm{C}$, relative humidity of $65-70 \%$, photoperiod of 14 -h light/ 10 -h dark, and photon flux density of $1.5 \times 10^{4}$ lux (lx). Ten days after seedling emergence, $25 \%$ Hoagland nutrient solution was supplied. One-month-old seedlings of uniform size were transferred into $2.5-\mathrm{L}$ black polyethylene pots (3 plants per pot) containing 50\% strength nutrient solution for a further two weeks pre-culture. The composition of the nutrient solution was as follows $\left(\mu \mathrm{mol} \mathrm{L}{ }^{-1}\right): \mathrm{Ca}\left(\mathrm{NO}_{3}\right)_{2} 1000, \mathrm{MgSO}_{4} 500, \mathrm{~K}_{2} \mathrm{HPO}_{4} 50$, $\mathrm{KCl} 100, \mathrm{H}_{3} \mathrm{BO}_{4} 10, \mathrm{MnSO}_{4} 1.8, \mathrm{Na}_{2} \mathrm{MoO}_{4} \quad 0.2, \mathrm{CuSO}_{4} 0.31$, $\mathrm{NiSO}_{4} 0.5, \mathrm{ZnSO}_{4} 5$ and $\mathrm{Fe}^{3+}$-EDTA 60 . The plants were then exposed to three concentrations of $\mathrm{Cu}$ : $0.31,50$ and $100 \mu \mathrm{mol}$
$\mathrm{L}^{-1}$. Copper was supplied as $\mathrm{CuSO}_{4}$. The pots were arranged in a completely randomized design with three replicates per treatment. The solutions were continuously aerated and renewed every four days. The solution $\mathrm{pH}$ was adjusted to $5.3 \pm 0.1$ with $0.1 \mathrm{~mol}$ $\mathrm{L}^{-1} \mathrm{HCl}$ or $\mathrm{NaOH}$ twice each day.

\subsection{Experimental procedure and methodology}

The plants were harvested after exposure to the $\mathrm{Cu}$ for 25 days. After measurement of shoot height, length of the longest root and root volume, the plants were separated into roots, stems and leaves. Roots were immersed in $20 \mathrm{mmol} \mathrm{L}^{-1} \mathrm{Na}_{2}$-EDTA for $15 \mathrm{~min}$ to remove the putative absorbed $\mathrm{Cu}^{2+}$ (Long et al., 2002). All parts were then rinsed with distilled water and dried firstly at $105{ }^{\circ} \mathrm{C}$ for $30 \mathrm{~min}$, oven-dried at $85{ }^{\circ} \mathrm{C}$ and weighed. The plant materials were milled with a stainless steel disintegrator. Sub-samples were digested with $85 \% \mathrm{HNO}_{3}$ and $15 \%$ $\mathrm{HClO}_{4}$ and multi-element analysis conducted by inductively coupled plasma-atomic emission spectrometry (ICP-AES) using an IRIS Intrepid spectrometer.

\subsection{Statistical analysis}

The Data Processing System for Windows (DPS Version 3.11) was employed for analysis of variance analysis and multiple comparisons (Tang and Feng, 2002). Pairs of mean values were compared using least significant difference (LSD) at the $5 \%$ level.

\section{Results and discussion}

\subsection{Effects of Cu on Elsholtzia plants}

Plants from the three populations of E. splendens grew well in the presence of 50 and $100 \mu \mathrm{mol} \mathrm{L}{ }^{-1} \mathrm{Cu}$ with a similar leaf colour to those grown under control conditions $\left(0.31 \mu \mathrm{mol} \mathrm{L}{ }^{-1} \mathrm{Cu}\right)$. In contrast, $E$. argyi appeared to exhibit $\mathrm{Cu}$ toxicity symptoms when grown with 50 and $100 \mu \mathrm{mol} \mathrm{L}{ }^{-1} \mathrm{Cu}$. Most of the leaves were purple in colour and chlorotic and some leaves fell from the plants in $100 \mu \mathrm{mol} \mathrm{L} \mathrm{L}^{-1} \mathrm{Cu}$. All the roots of E. splendens appeared healthy and strong, while $E$. argyi roots were black and weak when $\mathrm{Cu}$ was supplied at 50 and $100 \mu \mathrm{mol} \mathrm{L}{ }^{-1}$. The differences in plant

Table 1

Effects of elevated $\mathrm{Cu}$ on yield of four Elsholtzia ecotypes in solution culture ${ }^{\mathrm{a}}$

\begin{tabular}{|c|c|c|c|c|c|c|c|}
\hline \multirow[t]{2}{*}{ Elsholtzia ecotype } & \multirow{2}{*}{$\begin{array}{l}\mathrm{Cu} \text { treatment } \\
\left(\mu \mathrm{mol} \mathrm{L} \mathrm{L}^{-1}\right)\end{array}$} & \multirow{2}{*}{$\begin{array}{l}\text { Root length } \\
(\mathrm{cm})\end{array}$} & \multirow{2}{*}{$\begin{array}{l}\text { Root volume } \\
\left(\mathrm{cm}^{3} \text { plant }^{-1}\right)\end{array}$} & \multirow{2}{*}{$\begin{array}{l}\text { Shoot height } \\
(\mathrm{cm})\end{array}$} & \multicolumn{3}{|c|}{ Dry matter yield (g plant ${ }^{-1}$ ) } \\
\hline & & & & & Leaves & Stem & Roots \\
\hline \multirow[t]{3}{*}{ E. argyi, Sanmen population } & 0.31 & $41.5 \pm 2.4 \mathrm{a}$ & $13.6 \pm 0.8 \mathrm{a}$ & $16.6 \pm 0.9 \mathrm{a}$ & $1.5 \pm 0.1 \mathrm{a}$ & $0.42 \pm 0 \mathrm{a}$ & $0.79 \pm 0.1 \mathrm{a}$ \\
\hline & 50 & $14.8 \pm 1.2 \mathrm{~b}$ & $0.61 \pm 0.1 \mathrm{~b}$ & $6.50 \pm 0.3 b$ & $0.05 \pm 0 \mathrm{~b}$ & $0.02 \pm 0 \mathrm{~b}$ & $0.02 \pm 0 \mathrm{~b}$ \\
\hline & 100 & $19.1 \pm 4.2 \mathrm{~b}$ & $0.39 \pm 0.1 \mathrm{~b}$ & $6.61 \pm 0.3 \mathrm{~b}$ & $0.08 \pm 0 \mathrm{~b}$ & $0.02 \pm 0 \mathrm{~b}$ & $0.02 \pm 0 \mathrm{~b}$ \\
\hline \multirow[t]{3}{*}{ E. splendens, Jiande population } & 0.31 & $43.5 \pm 2.3 b$ & $18.1 \pm 3.4$ & $24.2 \pm 4.2$ & $1.75 \pm 0.5$ & $0.48 \pm 0.1$ & $1.05 \pm 0.4$ \\
\hline & 50 & $48.1 \pm 1.1 \mathrm{ab}$ & $23.9 \pm 6.7$ & $20.3 \pm 0.9$ & $1.42 \pm 0.1$ & $0.32 \pm 0$ & $0.72 \pm 0$ \\
\hline & 100 & $49.8 \pm 0.6 \mathrm{a}$ & $16.7 \pm 0.4$ & $20.5 \pm 1.5$ & $0.98 \pm 0.2$ & $0.20 \pm 0$ & $0.60 \pm 0$ \\
\hline \multirow[t]{3}{*}{ E. splendens, Tongling population } & 0.31 & $50.6 \pm 0.3$ & $13.2 \pm 0.4$ & $25.2 \pm 0.8 \mathrm{ab}$ & $1.81 \pm 0.3 \mathrm{a}$ & $0.48 \pm 0 \mathrm{a}$ & $0.67 \pm 0.1 \mathrm{a}$ \\
\hline & 50 & $44.1 \pm 9.2$ & $13.3 \pm 3.5$ & $26.4 \pm 0.3 \mathrm{a}$ & $1.34 \pm 0.1 \mathrm{a}$ & $0.38 \pm 0 \mathrm{a}$ & $0.55 \pm 0.1 \mathrm{ab}$ \\
\hline & 100 & $48.6 \pm 4.8$ & $8.3 \pm 2.2$ & $21.0 \pm 2.2 \mathrm{~b}$ & $0.43 \pm 0.1 \mathrm{~b}$ & $0.12 \pm 0 \mathrm{~b}$ & $0.30 \pm 0.1 \mathrm{~b}$ \\
\hline \multirow[t]{3}{*}{ E. splendens, Zhuji population } & 0.31 & $37.9 \pm 1.2$ & $11.5 \pm 1.8$ & $16.8 \pm 2.9$ & $1.58 \pm 0.2 \mathrm{a}$ & $0.27 \pm 0.1 \mathrm{a}$ & $0.46 \pm 0.1$ \\
\hline & 50 & $40.1 \pm 5.1$ & $12.7 \pm 3.5$ & $16.5 \pm 1.3$ & $1.15 \pm 0.1 \mathrm{~b}$ & $0.16 \pm 0 \mathrm{ab}$ & $0.32 \pm 0.2$ \\
\hline & 100 & $42.7 \pm 1.8$ & $10.1 \pm 2.1$ & $14.8 \pm 2.4$ & $0.77 \pm 0 \mathrm{~b}$ & $0.09 \pm 0 \mathrm{~b}$ & $0.35 \pm 0.2$ \\
\hline
\end{tabular}

${ }^{\mathrm{a}}$ Within each column, means followed by the same letter are not significantly different by LSD at the $5 \%$ level. 


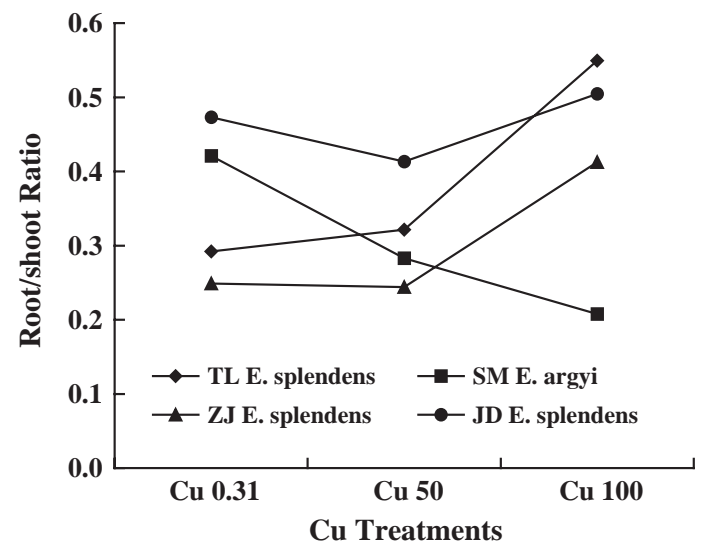

Fig. 1. Root-to-shoot ratios of Elsholtzia under $\mathrm{Cu}$ stress. TL, Tongling; SM, Sanmen; ZJ, Zhuji; JD, Jiande; all E. splendens except E. argyi at Sanmen.

morphology indicated that E. splendens tolerated $\mathrm{Cu}$ toxicity better than E. argyi.

The dry weight of $E$. argyi leaves, stems and roots showed a significant decline under 50 and $100 \mu \mathrm{mol} \mathrm{L} \mathrm{L}^{-1} \mathrm{Cu}$ compared with the control (Table 1), with total plant biomass declining by $97 \%$ and $95 \%$, respectively. In contrast, the biomass of the three E. splendens ecotypes remained unchanged. The root-to-shoot ratio of $E$. argyi decreased as $\mathrm{Cu}$ concentration increased (Fig. 1), while the root-to-shoot ratio of all three E. splendens ecotypes tended to increase, although the increases were not significant. Compared to the control, the root-to-shoot ratios of E. splendens under $100 \mu \mathrm{mol} \mathrm{Cu} \mathrm{L}{ }^{-1}$ increased by $6.0-39.0 \%$.

Table 2

Tolerance index of Elsholtzia ecotypes subjected to different $\mathrm{Cu}$ treatments ${ }^{\mathrm{a}}$

\begin{tabular}{|c|c|c|}
\hline Elsholtzia ecotype & $\begin{array}{l}\mathrm{Cu} \text { treatment } \\
\left(50 \mu \mathrm{mol} \mathrm{L}{ }^{-1}\right)\end{array}$ & $\begin{array}{l}\text { Cu treatment } \\
\left.(100 \mu \mathrm{mol} \mathrm{L})^{-1}\right)\end{array}$ \\
\hline E. argyi from Sanmen & $35.5 \pm 2.30 \mathrm{c}$ & $34.3 \pm 0.40 \mathrm{c}$ \\
\hline E. splendens from Jiande & $111 \pm 6.20 \mathrm{ab}$ & $115 \pm 8.80 \mathrm{a}$ \\
\hline E. splendens from Tongling & $102 \pm 13.5 \mathrm{~b}$ & $96.0 \pm 15.6 \mathrm{~b}$ \\
\hline E. splendens from Zhuji & $119 \pm 0.30 \mathrm{a}$ & $112 \pm 2.30 \mathrm{ab}$ \\
\hline
\end{tabular}

${ }^{\mathrm{a}}$ Within each column, means followed by the same letter are not significantly different by LSD at the $5 \%$ level.
This indicates that the plants developed more root biomass than shoot with an elevated $\mathrm{Cu}$ supply. Root lengths of $E$. argyi decreased significantly $(P<0.05)$ with increasing $\mathrm{Cu}$ concentration in solution. Although the root length of E. splendens from Tongling decreased slightly, root length of the other two $E$. splendens ecotypes increased slightly at elevated $\mathrm{Cu}$ levels.

The tolerance indices of the three E. splendens ecotypes were calculated by the equation described by Shu et al. (2002) as follows:

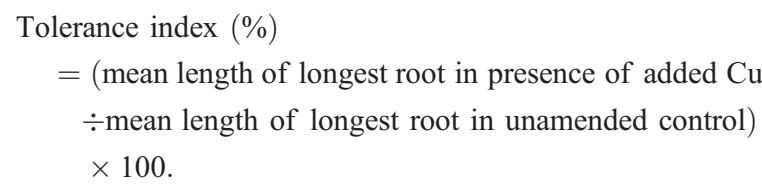

The tolerance indices of $E$. splendens to the two elevated $\mathrm{Cu}$ treatments were significantly higher than of $E$. argyi. E. splendens from Jiande and Zhuji was less sensitive to copper than the ecotype from Tongling, while E. argyi was the most sensitive to elevated $\mathrm{Cu}$. Root volume of the Elsholtzia plants showed similar trends to root length. However, the three $E$. splendens ecotypes exhibited maximum root volume and shoot height at $50 \mu \mathrm{mol} \mathrm{L} \mathrm{L}^{-1} \mathrm{Cu}$. The results indicate a greater $\mathrm{Cu}$ tolerance in E. splendens than in E. argyi (Table 2).

\subsection{Cu uptake by Elsholtzia plants}

All four Elsholtzia ecotypes exhibited healthy growth with plant $\mathrm{Cu}$ concentrations within normal limits in the control nutrient solution containing $0.31 \mu \mathrm{mol} \mathrm{Cu} \mathrm{L} \mathrm{L}^{-1}$ (Table 3). Plant $\mathrm{Cu}$ concentrations increased with increasing $\mathrm{Cu}$ supply. E. splendens from Tongling and E. argyi had higher leaf $\mathrm{Cu}$ concentrations than E. splendens from Jiande or Zhuji at a solution $\mathrm{Cu}$ concentration of $100 \mu \mathrm{mol} \mathrm{L}{ }^{-1}(P<0.05)$. Leaf $\mathrm{Cu}$ concentrations in these two $E$. splendens ecotypes were below $100 \mu \mathrm{g} \mathrm{g}^{-1}$ and were significantly $(P<0.05)$ different from that of $E$. splendens from Tongling and $E$. argyi. E. argyi thus accumulated more $\mathrm{Cu}$ than E. splendens $(P<0.01)$, and there was no significant difference in stem $\mathrm{Cu}$ concentration among the E. splendens ecotypes. In comparison with the control $\left(0.31 \mu \mathrm{mol} \mathrm{Cu} \mathrm{L}^{-1}\right)$, root $\mathrm{Cu}$ concentration increased sharply at $100 \mu \mathrm{mol} \mathrm{L}^{-1}$ added $\mathrm{Cu}$ in all Elsholtzia plants; for example, root $\mathrm{Cu}$ in E. argyi increased from 19 to 6319

Table 3

Plant $\mathrm{Cu}$ concentrations $\left(\mathrm{mg} \mathrm{kg}^{-1}\right)^{\mathrm{a}}$

\begin{tabular}{|c|c|c|c|c|c|c|}
\hline Elsholtzia ecotype & $\begin{array}{l}\text { Cu treatment } \\
\left(\mu \mathrm{mol} \mathrm{L} \mathrm{L}^{-1}\right)\end{array}$ & Leaves & Stem & Roots & $\begin{array}{l}\text { Total } \\
\text { aboveground }\end{array}$ & Whole plant \\
\hline \multirow{3}{*}{$\begin{array}{l}\text { E. argyi, Sanmen } \\
\text { population }\end{array}$} & 0.31 & $9.78 \pm 0.1 \mathrm{c}$ & $8.36 \pm 0.2 b$ & $19.2 \pm 1.6 \mathrm{c}$ & $9.50 \pm 0.1 \mathrm{c}$ & $12.3 \pm 0.4 \mathrm{~b}$ \\
\hline & 50 & $61.5 \pm 8.5 b$ & $134 \pm 35 \mathrm{~b}$ & $4391 \pm 134 \mathrm{~b}$ & $84.0 \pm 9.2 \mathrm{~b}$ & $1188 \pm 251 \mathrm{a}$ \\
\hline & 100 & $139 \pm 17.6 \mathrm{a}$ & $392 \pm 79 a$ & $6319 \pm 497 \mathrm{a}$ & $194 \pm 9.6 \mathrm{a}$ & $1293 \pm 217 \mathrm{a}$ \\
\hline \multirow{3}{*}{$\begin{array}{l}\text { E. splendens, Jiande } \\
\text { population }\end{array}$} & 0.31 & $5.95 \pm 0.7 \mathrm{~b}$ & $7.91 \pm 0.6 \mathrm{c}$ & $13.7 \pm 1.4 \mathrm{c}$ & $6.40 \pm 0.6 \mathrm{c}$ & $8.70 \pm 1.1 \mathrm{~b}$ \\
\hline & 50 & $15.4 \pm 1.7 \mathrm{~b}$ & $21.3 \pm 4.5 b$ & $364 \pm 98.6 \mathrm{~b}$ & $16.3 \pm 2.0 \mathrm{~b}$ & $117 \pm 29.6 \mathrm{~b}$ \\
\hline & 100 & $58.3 \pm 4.4 \mathrm{a}$ & $57.3 \pm 3.9 \mathrm{a}$ & $1394 \pm 122 \mathrm{a}$ & $58.1 \pm 4.3 \mathrm{a}$ & $513 \pm 51.6 \mathrm{a}$ \\
\hline \multirow{3}{*}{$\begin{array}{l}\text { E. splendens, Tongling } \\
\text { population }\end{array}$} & 0.31 & $5.75 \pm 0.3 \mathrm{~b}$ & $10.1 \pm 0.9 \mathrm{~b}$ & $16.0 \pm 1.3 \mathrm{~b}$ & $6.66 \pm 0.3 \mathrm{~b}$ & $8.70 \pm 0.1 \mathrm{~b}$ \\
\hline & 50 & $19.7 \pm 1.5 \mathrm{~b}$ & $23.7 \pm 1.0 \mathrm{~b}$ & $371 \pm 28.6 \mathrm{~b}$ & $20.5 \pm 1.2 \mathrm{~b}$ & $105 \pm 14.9 \mathrm{~b}$ \\
\hline & 100 & $147 \pm 36.0 \mathrm{a}$ & $124 \pm 21.4 \mathrm{a}$ & $2294 \pm 264 \mathrm{a}$ & $144 \pm 34.0 \mathrm{a}$ & $845 \pm 64.0 \mathrm{a}$ \\
\hline \multirow{3}{*}{$\begin{array}{l}\text { E. splendens, Zhuji } \\
\text { population }\end{array}$} & 0.31 & $6.50 \pm 0.7 \mathrm{~b}$ & $9.41 \pm 1.3 \mathrm{~b}$ & $16.9 \pm 0.4 \mathrm{~b}$ & $6.90 \pm 0.7 \mathrm{c}$ & $8.90 \pm 0.6 \mathrm{~b}$ \\
\hline & 50 & $26.8 \pm 5.5 \mathrm{~b}$ & $57.7 \pm 14.5 b$ & $432 \pm 57.4 \mathrm{~b}$ & $30.1 \pm 5.5 \mathrm{~b}$ & $91.7 \pm 19.2 \mathrm{ab}$ \\
\hline & 100 & $65.1 \pm 10.9 \mathrm{a}$ & $143 \pm 24.6 \mathrm{a}$ & $1965 \pm 342 \mathrm{a}$ & $71.9 \pm 8.3 \mathrm{a}$ & $574 \pm 244 \mathrm{a}$ \\
\hline
\end{tabular}

\footnotetext{
${ }^{a}$ Within each column, means followed by the same letter are not significantly different by LSD at the $5 \%$ level.
} 
$\mu \mathrm{g} \mathrm{g}^{-1} \mathrm{DM}$. Root $\mathrm{Cu}$ concentrations were significantly different between $E$. argyi and E. splendens, but there were no differences among the E. splendens ecotypes. It is a commonly observed phenomenon that plants can restrict heavy metal translocation from roots to shoots. In the present work roots usually showed higher $\mathrm{Cu}$ concentrations than shoots and the role of the roots may be very important in acting as a site for metal deposition and inactivation (Ouzounidou et al., 1995). As for the increase in root-to-shoot ratio with $\mathrm{Cu}$ addition, it is possible that a more rapid increase in the biomass of roots than of shoots may be one strategy leading to increased tolerance to $\mathrm{Cu}$ in E. splendens. Increased sequestration of $\mathrm{Cu}$ in the roots may help to protect the shoots from $\mathrm{Cu}$ toxicity. With $100 \mu \mathrm{mol} \mathrm{Cu} \mathrm{L} \mathrm{L}^{-1}$ in the nutrient solution, shoot $\mathrm{Cu}$ concentration reached $194 \mu \mathrm{g} \mathrm{g}^{-1} \mathrm{DM}$ in E. argyi and $144 \mu \mathrm{g}$ $\mathrm{g}^{-1} \mathrm{DM}$ in E. splendens from Tongling. According to Brooks (1998), $\mathrm{Cu}$ hyperaccumulators are defined as plants that accumulate $>1000 \mu \mathrm{g} \mathrm{Cu} \mathrm{g}^{-1} \mathrm{DM}$. Thus, E. argyi and E. splendens were not $\mathrm{Cu}$ hyperaccumulators under our experimental conditions. $E$. argyi was sensitive to $\mathrm{Cu}$ toxicity, while the three E. splendens ecotypes tolerated added $\mathrm{Cu}$ and behaved as $\mathrm{Cu}$ excluders (Song et al., 2004). Differences in $\mathrm{Cu}$ concentration were also found among the three E. splendens populations. Shoots of E. splendens from Tongling had a higher $\mathrm{Cu}$ concentrations than those of the other two E. splendens ecotypes.

Although the $\mathrm{Cu}$ concentrations in the plants were much lower than $1000 \mu \mathrm{g} \mathrm{g}^{-1}$, the plants may still have potential for phytostabilization since they can grow rapidly and grow in sites contaminated with mixtures of heavy metals. In our study, all the ecotypes showed their maximum $\mathrm{Cu}$ uptake under the highest $\mathrm{Cu}$ level. E. splendens from Tongling showed the highest $\mathrm{Cu}$ accumulation with up to $265 \mu \mathrm{g} \operatorname{pot}^{-1} \mathrm{Cu}$ in the shoots (Table 4).

Copper uptake in leaves plus roots amounted to $>80 \%$ of total plant uptake in control plants with the stems taking up $<20 \%$ of total plant $\mathrm{Cu}$ (Fig. 2). Root absorption increased sharply with $\mathrm{Cu}$ addition. When $\mathrm{Cu}$ was supplied at the level of $100 \mu \mathrm{mol} \mathrm{L}{ }^{-1}$, the proportion accumulated by the roots was similar in all four ecotypes and ranged from $87 \%$ to $93 \%$. The large amounts partitioned in the roots resulted from both high tissue concentrations in the roots and the increase in root-to-shoot ratio. Under high $\mathrm{Cu}$ treatments, nearly $60 \%$ the total $\mathrm{Cu}$ in roots may be bound to the cell wall fraction and the cell wall-plasma

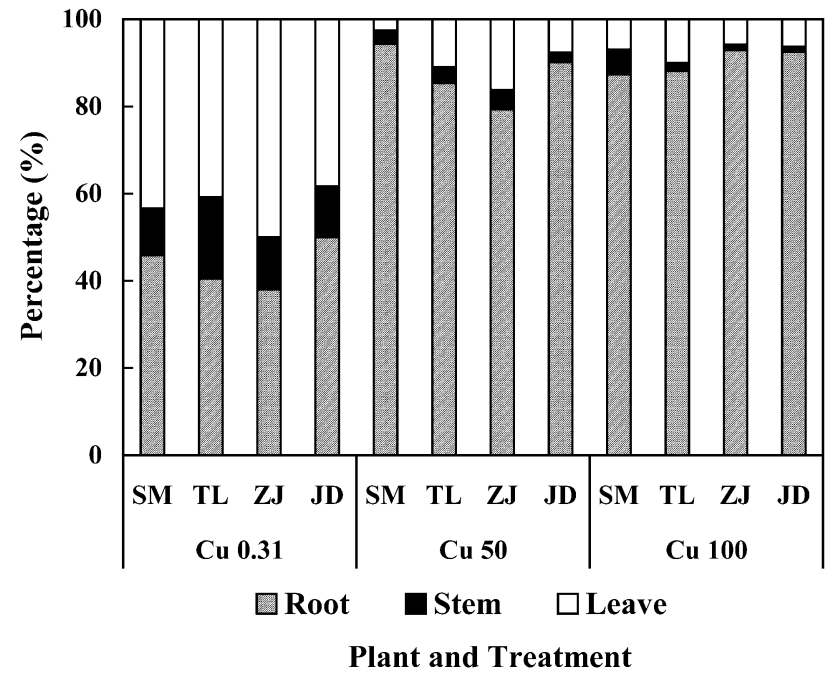

Fig. 2. Copper distribution in different plant parts. For legend of ecotypes, see Fig. 1.

membrane interface (Lin et al., 2003). Further studies are required to determine how the roots of E. splendens can tolerate and sequester $\mathrm{Cu}$. The large differences between root and leaf concentrations may indicate an important restriction of the internal transport of metal from the roots towards stems and leaves.

Yang et al. (2002) considered E. splendens to be a $\mathrm{Cu}$ hyperaccumulator because plants can accumulate $>1000 \mu \mathrm{g} \mathrm{Cu}$ $\mathrm{g}^{-1} \mathrm{DM}$ in their shoots. In the study by Yang et al. (2002), the highest $\mathrm{Cu}$ concentration in the nutrient solution was $1000 \mu \mathrm{M}$, 10 times higher than we used in our experiments, and under these conditions nutrient absorption may have been inhibited by the high $\mathrm{Cu}$ concentrations in the growth medium. However, in our study all three populations of $E$. splendens accumulated more $\mathrm{Cu}$ in their roots than in the shoots and shoot $\mathrm{Cu}$ concentrations increased with increasing addition of $\mathrm{Cu}$ added, thus they acted as $\mathrm{Cu}$ excluders. Song et al. (2004) also found that the wellknown Cu-tolerant species Silene vulgaris behaved as a typical $\mathrm{Cu}$ excluder. In common with other plant species, E. splendens accumulates most $\mathrm{Cu}$ in the roots. However, E. splendens can also grow naturally on $\mathrm{Cu}$-contaminated soils as a dominant

Table 4

Plant Cu uptake $\left(\mu \mathrm{g} \text { pot }^{-1}\right)^{\mathrm{a}}$

\begin{tabular}{|c|c|c|c|c|c|c|}
\hline Elsholtzia ecotype & $\begin{array}{l}\text { Cu treatment } \\
\left(\mu \mathrm{mol} \mathrm{L}{ }^{-1}\right)\end{array}$ & Leaf & Stem & Root & Aboveground & Whole plant \\
\hline \multirow[t]{3}{*}{ E. argyi, Sanmen population } & 0.31 & $42.6 \pm 4.2 \mathrm{a}$ & $10.6 \pm 2.1 \mathrm{~b}$ & $44.9 \pm 2.8 \mathrm{c}$ & $53.1 \pm 2.8 \mathrm{a}$ & $98.1 \pm 5.1 \mathrm{c}$ \\
\hline & 50 & $6.9 \pm 4.8 \mathrm{~b}$ & $8.5 \pm 2.3 b$ & $258 \pm 24$ a & $15.4 \pm 5.2 \mathrm{~b}$ & $273 \pm 23 b$ \\
\hline & 100 & $33.1 \pm 9.2 \mathrm{a}$ & $26.9 \pm 6.1 \mathrm{a}$ & $414 \pm 90 \mathrm{a}$ & $60.0 \pm 9.9 \mathrm{a}$ & $474 \pm 74$ a \\
\hline \multirow[t]{3}{*}{ E. splendens, Jiande population } & 0.31 & $35.9 \pm 17.4 \mathrm{~b}$ & $11.0 \pm 4.3 \mathrm{~b}$ & $46.8 \pm 40.6 \mathrm{~b}$ & $46.8 \pm 17.7 \mathrm{~b}$ & $93.7 \pm 50.6 \mathrm{c}$ \\
\hline & 50 & $66.5 \pm 18.9 \mathrm{~b}$ & $19.9 \pm 5.8 \mathrm{~b}$ & $785 \pm 384 b$ & $86.3 \pm 20.1 \mathrm{~b}$ & $872 \pm 329 b$ \\
\hline & 100 & $171 \pm 47 \mathrm{a}$ & $35.0 \pm 9.3 \mathrm{a}$ & $2521 \pm 512 \mathrm{a}$ & $206 \pm 44$ a & $2727 \pm 416$ a \\
\hline \multirow[t]{3}{*}{ E. splendens, Tongling population } & 0.31 & $31.7 \pm 12.0 \mathrm{~b}$ & $14.6 \pm 2.2 \mathrm{~b}$ & $31.5 \pm 4.1 \mathrm{~b}$ & $46.3 \pm 11.6 \mathrm{c}$ & $77.8 \pm 9.4 \mathrm{c}$ \\
\hline & 50 & $79.1 \pm 13.1 \mathrm{~b}$ & $26.8 \pm 3.1 \mathrm{ab}$ & $619 \pm 229 b$ & $106 \pm 13 \mathrm{~b}$ & $725 \pm 200 \mathrm{~b}$ \\
\hline & 100 & $224 \pm 60 \mathrm{a}$ & $40.8 \pm 17.4 \mathrm{a}$ & $1959 \pm 812 \mathrm{a}$ & $265 \pm 49 a$ & $2224 \pm 640$ a \\
\hline \multirow[t]{3}{*}{ E. splendens, Zhuji population } & 0.31 & $30.3 \pm 3.2 \mathrm{~b}$ & $7.2 \pm 0.6 \mathrm{~b}$ & $23.1 \pm 6.5 \mathrm{~b}$ & $37.5 \pm 2.4 \mathrm{c}$ & $60.5 \pm 7.6 \mathrm{~b}$ \\
\hline & 50 & $94.1 \pm 40.5 \mathrm{ab}$ & $26.0 \pm 12.8 \mathrm{a}$ & $461 \pm 126 b$ & $120 \pm 41 \mathrm{~b}$ & $581 \pm 100 \mathrm{~b}$ \\
\hline & 100 & $150 \pm 46 \mathrm{a}$ & $34.1 \pm 6.6 \mathrm{a}$ & $2412 \pm 1587 \mathrm{a}$ & $184 \pm 36 \mathrm{a}$ & $2596 \pm 1303 \mathrm{a}$ \\
\hline
\end{tabular}

${ }^{a}$ Within each column, means followed by the same letter are not significantly different by LSD at the $5 \%$ level. 
species, unlike many other species that cannot survive on $\mathrm{Cu}$ mine tailings. Lou et al. (2004) found that most of the $\mathrm{Cu}$ taken up by $E$. splendens was distributed in the cell walls and $\mathrm{Cu}$ was induced the synthesis of Cu-binding proteins together with low molecular substances such as organic acids, glutathione and amino acids in E. splendens roots. Our data indicate that E. splendens roots played an important role in $\mathrm{Cu}$ tolerance and detoxification in agreement with the results of Lou et al. (2004). The observed increases in of root-to-shoot ratio may enhance the effects of cell wall sequestration of $\mathrm{Cu}$ and may help to explain the ability of E. splendens to grow in soils highly contaminated with $\mathrm{Cu}$.

Most metal-contaminated soils are anthropogenically polluted and may be unstable and are therefore potential sources of air and water pollution. Establishment of vegetation cover may be essential to stabilize the soil and minimize the pollution risk. The choice of appropriate plant species will be important (Wong, 2003). Plant species that are suitable for phytostabilization should have a healthy root system, tolerate high levels of the target contaminants and retain contaminants in the roots with minimal accumulation in the shoots (Tang et al., 2001). All three populations of E. splendens show similar characteristics and may be suitable for phytostabilization of some $\mathrm{Cu}-$ contaminated soils. In fact, this species is often a natural colonizer of $\mathrm{Cu}$ mine spoil that prevents erosion of the substrate into rivers or groundwater. There is therefore an urgent need for field studies on the stabilization of $\mathrm{Cu}$-polluted sites by this plant species.

\section{Conclusions}

The roots of E. splendens may play an important role in $\mathrm{Cu}$ tolerance, as the root-to-shoot ratio and some indicators of root growth performance increased with increasing $\mathrm{Cu}$ level in the nutrient solution. There were some differences in $\mathrm{Cu}$ uptake capacity among the populations of $E$. splendens studied. Plants from the E. splendens Tongling population showed higher $\mathrm{Cu}$ accumulation than the other two E. splendens ecotypes. This plant species may have some potential for $\mathrm{Cu}$ phytoextraction, but is likely to be more suitable for $\mathrm{Cu}$ phytostabilization and further studies under field conditions are required.

\section{Acknowledgements}

We thank the Natural Science Foundation of China (Projects 40001013 and 40125005), the High Technology Research and Development Program of China (Project 2003AA645010-2) and the Major State Basic Research and Development Program of China (Project 2002CB410809/10) for funding this research.

\section{Reference}

Brooks RR. Plants that hyperaccumulate heavy metals. Wallingford: CAB International; 1998.

Lin J, Jiang WS, Liu DH. Accumulation of copper by roots, hypocotyls, cotyledons and leaves of sunflower (Helianthus annuus L). Bioresour Technol 2003;86:151-5.

Long XX, Yang XE, Ye ZQ, Ni WZH, Shi WY. Differences of uptake and accumulation of zinc in four species of Sedum (in Chinese). Acta Bot Sin 2002;44:152-7.

Lou LQ, Shen ZG, Li XD. The copper tolerance mechanisms of Elsholtzia haichowensis, a plant from copper-enriched soils. Environ Exp Bot 2004;51:111-20.

Ouzounidou G, Ciamporova M, Moustakas M. Responses of maize (Zea mays L.) plants to copper stress: I. Growth, mineral content and ultrastructure of roots. Environ Exp Bot 1995;35:167-76.

Shu WS, Ye ZH, Lan CY, Zhang ZQ, Wong MH. Lead, zinc and copper accumulation and tolerance in populations of Paspalum distichum and Cynodon dactylon. Environ Pollut 2002;120:445-53.

Song J, Zhao FJ, Luo YM, McGrath SP, Zhang H. Copper uptake by Elsholtzia splendens and Silene vulgaris and assessment of copper phytoavailability in contaminated soils. Environ Pollut 2004;128: $307-15$.

Tang QY, Feng MG. Data processing system for Windows $9 \mathrm{x} / 2 \mathrm{k} / \mathrm{xp}$ (in Chinese). Beijing, China: Science Press; 2002.

Tang SR, Wilke BM, Huang CY. The uptake of copper by plants dominantly growing on copper mining spoils along the Yangtze River, the People's Republic of China. Plant Soil 1999;209:225-32.

Tang SR, Wilke BM, Brooks R. Heavy metal uptake by metal-tolerant Elsholtzia haichowensis and Commelia communis from China. Commun Soil Sci Plant Anal 2001;32:895-905.

Wong MH. Ecological restoration of mine degraded soils, with emphasis on metal contaminated soils. Chemosphere 2003;50:775-80.

Yang MJ, Yang XE, Römheld V. Growth and nutrient composition of Elsholtzia splendens Nakai under copper toxicity. J Plant Nutr 2002; 25:1359-75. 